\title{
Thyrotoxic Hypokalaemic Periodic Paralysis: A Case Series from Trinidad, West Indies
}

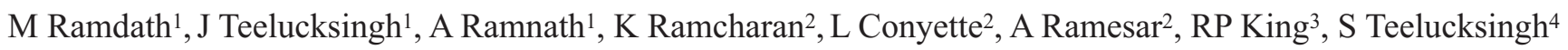

\begin{abstract}
We report our experience with seven cases of thyrotoxicosis associated with hypokalaemic periodic paralysis seen over a 25-year period in Trinidad, West Indies, an ethnically diverse island. All the cases were males, one was a Chinese, two were of East Indian and four of African descent, with a mean age 31.4 years (range 22-54 years). Early diagnosis and appropriate treatment led to the prompt resolution of the symptoms. Although rare in the Caribbean region, clinicians should be aware of the features of this potentially fatal but readily remediable complication of thyrotoxicosis.
\end{abstract}

Keywords: Hypokalaemia, hypokalaemic periodic paralysis, periodic paralysis, thyrotoxic periodic paralysis, Trinidad and Tobago, West Indies

\section{Parálisis Periódica Hipocalémica Tirotóxica: Un Estudio de Serie de Casos de Trinidad, West Indies}

M Ramdath ${ }^{1}$, J Teelucksingh ${ }^{1}$, A Ramnath ${ }^{1}$, K Ramcharan ${ }^{2}$, L Conyette ${ }^{2}$, A Ramesar ${ }^{2}$, RP King 3 , S Teelucksingh ${ }^{4}$

\section{RESUMEN}

Reportamos nuestra experiencia con siete casos de tirotoxicosis asociada con parálisis periódica hipocalémica observada por un periodo de 25 años en Trinidad, West Indies - una isla caracterizada por su diversidad étnica. En todos los casos se trató de hombres: uno era un chino, dos eran de la India, y cuatro de ascendencia africana, con una edad promedio de 31.4 años (rango 22 a 54 años). El diagnóstico precoz y un tratamiento adecuado llevaron a la pronta resolución de los síntomas. Aunque sea raro en la región del Caribe, los clínicos deben tener en cuenta que las características de esta complicación de la tirotoxicosis, potencialmente fatal pero fácilmente remediable.

Palabras claves: Hipocalemia, parálisis periódica hipocalémica, parálisis periódica, parálisis periódica tirotóxica (PPT), Trinidad y Tobago, West Indies.

From: ${ }^{1}$ Endocrinology Unit, San Fernando Teaching Hospital, University of the West Indies, San Fernando, Trinidad and Tobago, ${ }^{2}$ Neurology Unit, San Fernando Teaching Hospital, University of the West Indies, San Fernando, Trinidad and Tobago, ${ }^{3}$ Department of Medicine, St Augustine Private Hospital, St Augustine, Trinidad and Tobago and ${ }^{4}$ Endocrinology Unit, Medical Associates Hospital, St Joseph, Trinidad and Tobago.

Correspondence: Dr J Teelucksingh, Department of Medicine, San Fernando Teaching Hospital, San Fernando, Trinidad and Tobago, West Indies. Email: joeldavid2011@yahoo.co.uk

\section{INTRODUCTION}

Thyrotoxic periodic paralysis (TPP) is well manifested among Asian populations but has rarely been reported in the Caribbean region. This might be so because despite its ethnically diverse population, most of these Islands are dominated by peoples from Africa and India on whom reports are rare (1-3). Reports are also rare among other populations comprising Caucasians and 
Hispanics including Puerto Ricans in the West Indies (415). We here report on seven cases of TPP seen and managed by one or more of us in Trinidad over a 25-year period. The Trinidadian population comprises 1.3 million people of predominantly African and Indian descent with $1 \%$ Asians, Caucasians, Hispanics and an increasing proportion of those with mixed ethnicities. This ethnic background, with few Asians, may explain the relatively low incidence of TPP in this population. Despite this, clinicians should be aware of this eminently treatable complication of thyrotoxicosis.

\section{Case 1}

A previously well 22-year-old Chinese male who was born in China and migrated to Trinidad in his childhood presented with sudden inability to walk. His sister had myasthenia gravis and he denied any symptoms of thyroid disease. On admission, he was afebrile with a blood pressure of $130 / 70 \mathrm{mmHg}$ and heart-rate of 112 beats per minute. His physical examination showed that he had a Grade 3/5 (MRC scale) proximal muscle weakness affecting mainly the lower limbs but with intact sensation. There was a mildly enlarged, diffuse thyroid gland without pre-tibial myxoedaema or ophthalmopathy. Biochemical investigations showed a serum potassium of 2.2 mmol/L (ref: $3.5-5.1 \mathrm{mmol} / \mathrm{L}$ ), TSH $0.01 \mu \mathrm{IU} / \mathrm{mL}$ (ref: $0.27-4.2 \mu \mathrm{IU} / \mathrm{mL}$ ), free $\mathrm{T}_{4} 15.2 \mu \mathrm{g} / \mathrm{dL}$ (ref: $0.27-4.2$ $\mu \mathrm{IU} / \mathrm{mL}$ ), free $\mathrm{T}_{4} 15.2 \mu \mathrm{g} / \mathrm{dL}$ (ref: $5.1-14.1 \mu \mathrm{g} / \mathrm{dL}$ ), free $\mathrm{T}_{3} 6.9 \mathrm{ng} / \mathrm{ML}$ (ref: $0.8-2 \mathrm{ng} / \mathrm{mL}$ ) and creatinine kinase 300U/L (ref: 100-225 U/L). Electrocardiogram showed a sinus tachycardia. Thyroid ultrasound revealed diffuse enlargements of both lobes and thyroid autoantibodies were positive. A diagnosis of thyrotoxic hypokalaemic periodic paralysis was made. Treatment was initiated with oral propranolol and carbimazole as well as intravenous potassium chloride for two days (Table 1). Serum potassium on his discharge was $4.0 \mathrm{mmol} / \mathrm{L}$ and remained normal at six weeks follow-up without additional potassium supplementation. His thyrotoxicosis was treated medically for two years and he remained in remission.

\section{Case 2}

A previously well 25-year-old Afro-Caribbean male presented with a one-day history of proximal muscle weakness affecting both upper and lower limbs. There was no history of muscle pain, sensory abnormalities or sphincter disturbances. He had no significant personal or familial medical history and he was not taking any medication.
On admission, he was afebrile with a blood pressure of $129 / 79 \mathrm{mmHg}$ and heart-rate of 124 beats per minute. His physical examination showed that he had a mild proximal limb weakness with Grade $4 / 5$ power (MRC scale), normal reflexes and intact sensation. His thyroid examination showed that he had a diffusely enlarged goiter with a bruit but no dysthyroid eye disease, acropachy or pretibial myxoedaema. His cardiovascular, respiratory and abdominal examinations were unremarkable.

His biochemical investigations showed serum potassium $2.0 \mathrm{mmol} / \mathrm{L}$ (ref: $3.5-5.1 \mathrm{mmol} / \mathrm{L}$ ), TSH 0.01 $\mu \mathrm{IU} / \mathrm{mL}$ (ref: $0.27-4.2 \mu \mathrm{IU} / \mathrm{mL}$ ), free $\mathrm{T}_{4} 17.7 \mu \mathrm{g} / \mathrm{dL}$ (ref: $5.1-14.1 \mu \mathrm{g} / \mathrm{dL}$ ), free $\mathrm{T}_{3} 5.2 \mathrm{ng} / \mathrm{mL}$ (ref: $0.8-2 \mathrm{ng} / \mathrm{mL}$ ) and creatinine kinase $350 \mathrm{U} / \mathrm{L}$ (ref: 100-225 U/L). Sinus tachycardia was noted on electrocardiography and thyroid ultrasound confirmed diffuse homogenous enlargements of both lobes. His treatment was initiated with propranolol, carbimazole and intravenous potassium chloride (Table 1). His serum potassium on discharge was $4.2 \mathrm{mmol} / \mathrm{L}$ and he remained normal at three weeks follow-up without additional potassium supplementation. His thyrotoxicosis was treated with carbimazole in the longer term and the patient achieved biochemical and clinical remission.

\section{Case 3}

A 54-year-old hyperthyroid Afro-Trinidadian male presented with a one-month history of proximal muscle weakness affecting both upper and lower limbs. He was on antithyroid medications for three years but had been non-compliant. He also experienced weight-loss of about 10 pounds over three weeks, hyperhidrosis, tremors, irritability, hoarseness of voice, heat intolerance and occasional chest pains. There was no significant family history or recent antecedent viral illness.

On admission, he was afebrile with a blood pressure of $110 / 69 \mathrm{mmHg}$ and heart-rate of 94 beats per minute. His physical examination showed that he had a mild proximal limb weakness with normal tone, Grade $4 / 5$ power in the proximal muscles (MRC scale) and normal reflexes. His cardiovascular, abdominal, respiratory and thyroid examinations were unremarkable. His electrocardiogram was normal.

The patient's biochemical examination revealed the following; TSH $0.02 \mu \mathrm{IU} / \mathrm{mL}$ (ref: $0.27-4.2 \mu \mathrm{IU} / \mathrm{mL}$ ), free $\mathrm{T}_{3} 18.89 \mathrm{ng} / \mathrm{mL}$ (ref: $1.7-3.7 \mathrm{ng} / \mathrm{mL}$ ), free $\mathrm{T}_{4} 4.77$ $\mu \mathrm{g} / \mathrm{dL}$ (ref: $0.7-1.8 \mathrm{ug} / \mathrm{dL}$ ), potassium $2.9 \mathrm{mmol} / \mathrm{L}$ (ref: 3.5-5.1 mmol/L), creatinine kinase 79 U/L (ref: 100-225 $\mathrm{U} / \mathrm{L}$ ). His thyroid ultrasound showed a normal-sized, 
non-nodular gland and his thyroid autoantibodies were negative. His treatment was initiated with propranolol, carbimazole and intravenous potassium chloride for a few days (Table 1). His serum potassium on discharge was $4.4 \mathrm{mmol} / \mathrm{L}$ and he remained normal thereafter. He has been euthyroid on carbimazole and has been referred for radioiodine treatment.

\section{Case 4}

A 24-year-old Afro-Trinidadian, with a six month history of Graves' disease presented with bilateral lower limb weakness of two days duration. He also experienced myalgia, dyspnoea, palpitations, irritability, diaphoresis, sweating and weight-loss of 30 pounds over six months. There was no history of trauma or bowel and bladder symptoms. He had a family history of thyroid disease and was taking herbal medications. On admission, he was afebrile with a blood pressure of $153 / 81 \mathrm{mmHg}$ and heart-rate of 80 beats per minute. His physical examination revealed that he had a decreased tone, power Grade 3/5 (MRC scale) and absent reflexes affecting the lower limbs with normal sensation. He had a diffusely enlarged thyroid gland with exophthalmos and a bruit but no pretibial myxoedaema or acropachy. His cardiovascular, abdominal and respiratory examinations were unremarkable.

His biochemical investigations showed that he had TSH $0.01 \mu \mathrm{IU} / \mathrm{mL}$ (ref: $0.27-4.2 \mu \mathrm{IU} / \mathrm{mL}$ ), free $\mathrm{T}_{4} 17.0$ $\mu \mathrm{g} / \mathrm{dL}$ (ref: $5.1-14.1 \mu \mathrm{g} / \mathrm{dL}$ ), free $\mathrm{T}_{3} 5.2 \mathrm{ng} / \mathrm{mL}$ (ref: $0.8-$ $2 \mathrm{ng} / \mathrm{mL}$ ), creatinine kinase $539 \mathrm{U} / \mathrm{L}$ (ref: 100-225 U/L) and potassium $1.5 \mathrm{mmol} / \mathrm{L}$ (ref: $3.5-5.1 \mathrm{mmol} / \mathrm{L}$ ). His electrocardiogram was normal. His treatment was initiated with propranolol, carbimazole and intravenous potassium chloride for a few days (Table 1). His serum potassium on discharge was $4.4 \mathrm{mmol} / \mathrm{L}$ and he remained normal at six weeks follow-up without any need for additional supplementation. He remains biochemically euthyroid on carbimazole.

\section{Case 5}

A 45-year-old Afro-Caribbean male noticed his sudden inability to walk which prompted his admission to hospital. He was afebrile with a blood pressure of 110/70 $\mathrm{mmHg}$ and pulse of 110 beats per minute. His physical examination was normal except for the Grade 3/5 power in his lower limbs and 4/5 in his upper limbs (MRC scale). His serum potassium was $2.5 \mathrm{mmol} / \mathrm{L}$ (ref: $3.5-$ $5.1 \mathrm{mmol} / \mathrm{L}$ ) and he had diffuse thyroid enlargement with a bruit. His ultrasonography confirmed a non-nodular goiter; and his thyroid autoantibodies were positive.
His TSH was $0.02 \mu \mathrm{IU} / \mathrm{mL}$ (ref: $0.27-4.2 \mu \mathrm{IU} / \mathrm{mL}$ ), total $\mathrm{T}_{4} 10.0 \mu \mathrm{g} / \mathrm{dL}$ (ref: $4.5-11.5 \mu \mathrm{g} / \mathrm{dL}$ ), Total $\mathrm{T}_{3} 5.6 \mathrm{ng} / \mathrm{mL}$ (ref: $0.8-2.0 \mathrm{ng} / \mathrm{mL}$ ) and creatinine kinase was $150 \mathrm{U} / \mathrm{L}$ (ref: 100-225 U/L). His Electrocardiogram showed sinus tachycardia. He was successfully treated with propranolol, carbimazole and potassium supplementation. His serum potassium on discharge was $4.1 \mathrm{mmol} / \mathrm{L}$. After antithyroid drug treatment for 18 months, he remains clinically and biochemically euthyroid.

\section{Case 6}

A 23-year-old East-Indian male presented with weightloss of ten pounds and inability to walk for a few hours. He was referred as a case of possible Guillain-Barre syndrome and had a sister who had developed severe Rheumatoid Arthritis at the age of 21 years.

He was afebrile with a blood pressure of $120 / 82$ $\mathrm{mm} \mathrm{Hg}$ and heart-rate of 120 beats per minute. On his physical examination, there was a (mild) diffuse enlargement of his thyroid gland with no opthalmopathy, acropachy or pretibial myxoedaema. His power was $2 / 5$ in the lower limbs and 3/5 in the upper limbs (MRC scale). His blood investigations revealed serum potassium of $2.3 \mathrm{mmol} / \mathrm{L}$ (ref: $3.5-5.1 \mathrm{mmol} / \mathrm{L}$ ), TSH 0.04 $\mu \mathrm{IU} / \mathrm{mL}$ (ref: $0.27-4.2 \mu \mathrm{IU} / \mathrm{mL}$ ), Total $\mathrm{T}_{3} 6.3 \mathrm{ng} / \mathrm{mL}$ (ref: 0.8-2.0 ng/mL), Total $\mathrm{T}_{4} 12.1 \mu \mathrm{g} / \mathrm{dL}$ (ref:4.5-11.5 $\mu \mathrm{g} / \mathrm{dL}$ ) and creatinine kinase of $120 \mathrm{U} / \mathrm{L}$ (ref: 100-225 $\mathrm{U} / \mathrm{L}$ ).

His thyroid ultrasound and thyroid autoantibodies were consistent with autoimmune Thyroid disease. His electrocardiogram showed sinus tachycardia and prominent $\mathrm{U}$ waves. Following treatment with oral propranolol, carbimazole with intravenous potassium and oral potassium for two days, his symptoms were resolved. His serum potassium on discharge was $4.2 \mathrm{mmol} / \mathrm{L}$. His thioamide therapy was continued for 18 months and he has remained euthyroid.

\section{Case 7}

A 37-year-old male of East-Indian descent was admitted to hospital with acute onset of weakness and shortness of breath. For six weeks before, he had experienced insomnia, irritability and weight-loss. His mother and sister were both treated for thyrotoxicosis. On his examination, he had a small diffuse goiter, tachycardia, generalized muscle weakness (grade $3-4$ proximally and grade 4-5 distally) with diminished reflexes. He had no dysphagia, dysphonia, ptosis nor diplopia. His serum potassium was $2.3 \mathrm{mmol} / \mathrm{L}$ (ref: $3.5-5.1 \mathrm{mmol} / \mathrm{L}$ ) and serum phosphorus was $2.0 \mathrm{mg} / \mathrm{dL}$ (ref: $2.5-5.0 \mathrm{mg} / \mathrm{dL}$ ) 
but his calcium and magnesium were both normal. His serum free $\mathrm{T}_{4}$ was $2.8 \mathrm{ng} / \mathrm{dL}$ (ref: $0.71-1.85 \mathrm{ng} / \mathrm{dL}$ ) and TSH was suppressed below the reference range for the assay. His creatinine kinase was 173 u/L (ref: 29-200 $\mathrm{u} / \mathrm{L}$ ). The patient's thyroid scintigraphy revealed a diffuse increased uptake pattern of 7\% (ref: $1-4 \%$ ); but his thyroid antiperoxidase antibodies were positive.

He was treated with intravenous potassium chloride by slow intravenous infusion, oral propranolol $40 \mathrm{mg}$ thrice daily and carbimazole $30 \mathrm{mg}$ daily. His serum potassium rose to $4.3 \mathrm{mmol} / \mathrm{L}$ and remained within normal limits until his discharge two days later. The patient subsequently received radioiodine treatment and became hypothyroid seven months after his post-radioiodine treatment. He is currently on L-thyroxine replacement and has never experienced another episode of hypokalaemic weakness. The details of cases are shown in the Table 1.

\section{DISCUSSION}

Periodic paralysis was first described in 1874 by Hartwig (16). The association between thyrotoxicosis and periodic paralysis was first reported by Rosenfeld in 1902 (17). It is known to occur predominantly among young Asian males, although it has also been reported in American Indians, Mexican Mestizos, Europeans as well as Turkish citizens and amongst others previously mentioned (18-20). Recent studies from the Indian subcontinent have confirmed the rarity in Indians and there are similarly, few reports from continental Africa $(21,22)$. Male-to-female ratios vary from 17:1 to 20:1 in Japan, 33:1 to 48:1 in the United States of America and 76:1 in Southern China (12, 23-25). Mortality and significant morbidity are associated with TPP; though uncommon (26). Male predominance of TPP is well established and is consistent with our experience. The association of TPP with the presence of certain human leukocyte antigen

Table: Demographics, clinical features, investigations and response to treatment in seven multi-ethnic males

\begin{tabular}{|c|c|c|c|c|c|c|c|}
\hline CASE & 1 & 2 & 3 & 4 & 5 & 6 & 7 \\
\hline Age & 22 & 25 & 54 & 24 & 45 & 23 & 37 \\
\hline Gender & $\mathrm{M}$ & $\mathrm{M}$ & $\mathrm{M}$ & M & $\mathrm{M}$ & $\mathrm{M}$ & $\mathrm{M}$ \\
\hline Ethnicity & Chinese & African & African & African & African & Indian & Indian \\
\hline ECG & $\begin{array}{l}\text { Sinus } \\
\text { tachycardia }\end{array}$ & $\begin{array}{l}\text { Sinus } \\
\text { tachycardia, }\end{array}$ & Normal & Normal & $\begin{array}{l}\text { Sinus } \\
\text { tachycardia }\end{array}$ & $\begin{array}{l}\text { Sinus } \\
\text { tachycardia } \\
\text { Prominent U } \\
\text { wave }\end{array}$ & $\begin{array}{l}\text { Sinus } \\
\text { tachycardia }\end{array}$ \\
\hline $\begin{array}{l}\mathrm{K} \\
(\mathrm{mmol} / \mathrm{L})\end{array}$ & 2.2 & 2.0 & 2.9 & 1.5 & 2.5 & 2.3 & 2.3 \\
\hline $\begin{array}{l}\mathrm{K} \text { on discharge } \\
(\mathrm{mmol} / \mathrm{L})\end{array}$ & 4.0 & 4.2 & 4.4 & 4.4 & 4.1 & 4.2 & 4.3 \\
\hline $\begin{array}{l}\mathrm{CK} \\
(\mathrm{U} / \mathrm{L})\end{array}$ & 300 & 350 & 79 & 539 & 150 & 120 & 173 \\
\hline $\begin{array}{l}\text { TSH } \\
(\mathrm{uIU} / \mathrm{mL})\end{array}$ & 0.01 & 0.01 & 0.02 & 0.01 & 0.02 & 0.04 & - \\
\hline $\begin{array}{l}\text { Free } T_{4} \\
(\mu \mathrm{g} / \mathrm{dL})\end{array}$ & 15.2 & 17.7 & 4.77 & 17.0 & - & - & 2.8 \\
\hline $\begin{array}{l}\text { Free } T_{3} \\
(\mathrm{ng} / \mathrm{mL})\end{array}$ & 6.9 & 5.2 & 18.9 & 5.2 & - & - & - \\
\hline $\begin{array}{l}\text { Total } \mathrm{T}_{4} \\
(\mu \mathrm{g} / \mathrm{dL})\end{array}$ & - & - & - & - & 10.0 & 12.1 & - \\
\hline $\begin{array}{l}\text { Total } \mathrm{T}_{3} \\
(\mathrm{ng} / \mathrm{dL})\end{array}$ & - & - & - & - & 5.6 & 6.3 & - \\
\hline GOITRE & $\mathrm{NO}$ & YES & $\mathrm{NO}$ & YES & YES & YES & YES \\
\hline
\end{tabular}


(HLA) subtypes; in particular, HLA - DRw8 suggests that the basic defect may be genetically linked (27). Da Silva et al described a genetic mutation in TPP that has been linked to the potassium ionic channel gene KCNE3 (28). Ryan et al discovered that mutations in an inward rectifying potassium channel (Kir) Kir2.6 can contribute to TPP (29). These inward rectifying potassium channels function to move potassium ions into the cells of the cardiac and skeletal muscles. The mutations in the Kir2.6 channels can lead to altered membrane excitability, particularly in thyrotoxic individuals when challenged with massive intracellular potassium influx from heightened $\mathrm{Na}+/ \mathrm{K}+$-ATPase activity. The latter event is thought to be mediated by thyroid hormone.

Prompt diagnosis with immediate treatment of TPP is essential. The diagnosis of TPP should be particularly considered in young males presenting with acute muscle weakness, severe paralysis and a history of recurrent similar attacks with quick recovery. The absence of clinical or previous evidence of thyrotoxicosis does not exclude its diagnosis. As seen in our patients, Cases 3, 4 and 7 presented with a history of hyperthyroidism whereas the other four patients lacked any significant medical or family history of thyroid disease. The onset of paralysis usually coincides with the onset of hyperthyroidism. However, these symptoms if present, are often mild (27, 30). Thyrotoxic periodic paralysis has also been noted with thyroiditis, toxic adenoma, toxic nodular goiter, $\mathrm{TSH}$-secreting pituitary adenoma, ingestion of $\mathrm{T}_{4}$ or $\mathrm{T}_{3}$, inadvertent iodine excess, subacute thyroiditis of de Quervain, amiodarone therapy, radiation thyroiditis with Graves' disease and nutraceuticals containing tiratricol (31). All the cases in the current series were consistent with the diagnosis of Graves' disease.

The precipitating elements for TPP include: exposure of people to cold environments, a heavy carbohydrate meal, infection, strenuous exercise, menstruation and emotional stress. However, there were no identifiable or obvious triggers in any of our patients. The severity of hyperthyroidism is poorly associated with TPP attacks. There are recent reports showing that the hyperthyroidism may be 'clinically silent' $(27,30)$. Thus, TPP may be an early manifestation and presenting feature of thyrotoxicosis.

Some electrocardiographic aspects that can suggest a diagnosis of TPP are sinus tachycardia which was apparent in our patients from Cases 1, 2, 5, 6 and 7, respectively. Other electrocardiographic features include: atrial fibrillation, ventricular fibrillation, atrio-ventricular block and asystole. Prolonged QT-U interval associated with hypokalaemia and a paradoxically prolonged PR interval due to thyrotoxicosis are also common. The most prevalent finding in our patients was sinus tachycardia with one case showing a prominent $\mathrm{U}$ wave (Case 6).

The treatment of TPP requires urgent correction of potassium levels. Paul et al demonstrated that potassium replacement should be tailored according to patients' symptoms and potassium levels upon presentation (32). For potassium concentrations above $2.5 \mathrm{mmol} / \mathrm{L}$ and patients presenting with mild weakness, treatment should be initiated with $80 \mathrm{mmol} / 24$ hours of oral potassium. Patients presenting with potassium concentrations below $2.5 \mathrm{mmol} / \mathrm{L}$ or with symptoms of paralysis should be treated with intravenous potassium. As serum potassium concentrations rise, oral potassium supplements should be administered. In treating TPP with intravenous potassium, close monitoring of plasma potassium is essential to prevent the rebound of hyperkalaemia, particularly since the hypokalaemia is due to transcellular shift rather than potassium depletion. The total potassium replacement required for the correction of hypokalaemia in TPP is relatively small compared to that seen in other causes of hypokalaemia where a potassium deficit exists. Continuous ECG monitoring to check for arrhythmias, peak flows and serial arterial blood gases to monitor respiratory function should be performed (32).

The treatment of hyperthyroidism is essential in the management of TPP. The current practice is to use propranolol, propylthiouracil or carbimazole to establish rapid control of the thyrotoxicosis followed by ablative radioactive iodine therapy in the majority of cases (32).

The most successful drug in the management of TPP is propranolol. Propranolol, added to the initial treatment, has been shown to counteract the peripheral effects of thyrotoxicosis and thus, it improves muscle strength (26). Thyroid hormone directly stimulates $\mathrm{Na}+/ \mathrm{K}+-\mathrm{AT}$ Pase activity in the skeletal muscle, liver and kidney. It also increases the number and sensitivity of $\beta$-receptors, which causes increased catecholamine-mediated potassium uptake $(33,34)$. The increased $\beta$-adrenergic stimulation results in further increased $\mathrm{Na}+/ \mathrm{K}+$-ATPase activity. Thus, by blunting the hyper-adrenergic state, $\beta$ blockers can prevent the attacks of TPP $(12,30,33,35$, 36). This was clearly seen on the initiation of treatment in our patients having reported significant improvement in muscle power. Nonetheless, long-term treatment of TPP requires the necessary concomitant control of hyperthyroidism (37). In summary, we wish to highlight, 
by this report, that in multiethnic societies, such as in the West Indies, TPP can occur in any patient.

\section{ACKNOWLEDGEMENTS}

We thank our colleagues who assisted us with the care of these patients.

\section{REFERENCES}

1. Arthurs M, Morgan OS, Venkatesh S, Char G, Kelly D, Barrow KO. Thytrotoxic periodic paralysis in a Jamaican male patient. West Indian Med J 1992; 2: 81-3.

2. Iheonuneku NC, Ibrahim TM, Davies D, Pickering K. Thyrotoxic hypokalemic periodic paralysis in a pregnant AfroCaribbean woman - A case report and review of literature. West Indian Med J 2004; 53: 47-9.

3. Walters WA $3^{\text {rd }}$, Han SW, Schoffstall J. Thyrotoxic periodic paralysis in a Jamaican man. J Emerg Med 1999; 17: 47-51.

4. Wang X, Chow CC, Yao X, Ko GT, Cockram CS, Kwok HK et al. The predisposition to thyrotoxic periodic paralysis (TPP) is due to a genetic variant in the inward-rectifying potassium channel, KCNJ2. Clin Endocrinol 2014; 80: 770-1.

5. Kumar V, Momgroy L, Seshari MS, Finny P. Hypokalemic periodic paralysis in rural north India - must have secondary cause. Trop Doct 2014; 44: 33-5.

6. Chatot-Henry C, Smadja D, Longhi R, Brebion A, Sobeksy G. Thyrotoxic periodic paralysis: two new cases in Blacks. Rev Med Interne 2000; 21: 632-4.

7. Salifu MO, Otah K, Caroll HJ, Ifudu O, Friedman EA, Oh MS et al. Thyrotoxic hypokalemic periodic paralysis in a Black man .QJ Med 2001; 94: 659-60.

8. Schoumaker V, Bovy P. Clinical case of the month. Thyrotoxic periodic paralysis. Report of a case in a Somalian male. Rev Med Liege 2013; 68: 402-7.

9. Patel H, Wilches LV, Guerrero J. Thyrotoxic periodic paralysis: diversity in America. J Emerg Med 2013; pii: SO736-4679 (13) 01997-4.

10. Saeian K, Heckerling PS. Thyrotoxic periodic paralysis in a Hispanic man. Arch Intern Med 1988; 148: 708.

11. Matta A, Koppala J, Gossman W. Thyrotoxic hypokalaemic periodic paralysis: a rare presentation of Graves' disease in a Hispanic patient; April 9; 2014 pii: bcr2014204198. doi: 10.1136/ bcr-2014-204198.

12. Ober KP. Thyrotoxic periodic paralysis in the United States. Report of 7 cases and review of the literature. Medicine1992; 71: 109-20.

13. Ramirez-Rivera J, Flores AD. Sudden periodic paralysis: a rare manifestation of thyrotoxicosis. Bol Asoc Med P R. 1998; 90: 88-90.

14. Palermo-Garófalo CA, Martinez JH, De Lourdes Miranda M, Fernández R, Viñuela A. An unusual cause of muscle weakness: a diagnostic challenge. Bol Asoc Med P R 2011; 103: 54-6.

15. Gómez JY, Bravo-Llerena WE, Reyes-Ortiz LM, ValderrábanoWagner RJ, Mariano-Mejías V, Brunet-Rodríguez H et al. Thyrotoxic periodic paralysis is a rare but potentially fatal emergency: case report and literature review. Bol Asoc Med P R 2011; 103: 67-74.

16. Hartwig H. UebereinenFall bon intermittirender Paralysis spinalis. Inaugural dissertation. Halle, Germany, Lipke, 1874.
17. Rosenfeld M. Acute aufsteigende lahmung bei morbus basedow. Klin Wochenschr (Bed) 1902; 39: 538-40.

18. Conway MJ, Seibel JA, Eaton P. Thyrotoxicosis and periodic paralysis: improvement with beta-blockade. Ann Intern Med 1974; 81: 332-6.

19. Cesur M, Bayram F, Temel MA, Ozakaya M, Kocer A, Ertore ME et al. Thyrotoxichypokalemic periodic paralysis in a Turkish population; three new case reports and analysis of the case series. Clin Endocrinol 2008; 68: 143-52.

20. Nellen H, Mercado M, Mendoza V, Villanueva S, Pérez M, Hernández A et al. Thyrotoxic periodic paralysis in Mexican Mestizo patients: a clinical biochemical and HLA-serological study. Arch Med Res 1999; 30: 74-6.

21. Ajayi NA. Thyrotoxic periodic paralysis in a Nigerian: a case report. J Dent Med Sci 2012; 1: 5-7.

22. Tessier JJ, Neu SK, Horning KK. Thyrotoxic periodic paralysis (TPP) in a 28-year-old Sudanese man started on prednisone. J Am Board Fam Med 2010; 23: 551-54.

23. Satoyoshi E, Murakami K, Kowa H, Kinoshita M, Nishiyama Y. Periodic paralysis in hyperthyroidism. Neurology 1963; 13: 74652.

24. Okinaka S, Shizume K, Lino S, Watanabe A, Irie M, Noguchi A et al. The association of periodic paralysis and hyperthyroidism in Japan. J Gin Endocrine Metabol 1957; 17: 1454-9.

25. McFadzean AJ, Yeung R. Periodic paralysis complicating thyrotoxicosis in Chinese. Br Med J 1967; 1: 451-5.

26. Ko GTC, Chow CC, Yeung VTF, Chan HH, Li JK, Cockram CS. Thyrotoxic periodic paralysis in a Chinese population. QJM 1996; 89: 463-8.

27. Magsino CH Jr, Ryan AJ Jr. Thyrotoxic periodic paralysis. South Med J 2000; 93: 996-1003.

28. Da Silva MRD, Cerutti JM, Arnaldi LA, Maciel RM. A mutation in the KCNE3 potassium channel gene is associated with susceptibility to thyrotoxic hypokalaemic periodic paralysis. J Clin Endocrinol Metab 2002; 87: 4881-4.

29. Ryan DP, da Silva MR, Soong TW, Fontaine B, Donaldson MR, Kung AW et al. Mutations in the potassium channel Kir2.6 cause susceptibility to thyrotoxic hypokalemic periodic paralysis. Cell 2010; 140: 88-98.

30. Kelley DE, Gharib H, Kennedy FP, Duda RJ Jr, McManis PG. Thyrotoxic periodic paralysis. Report of 10 cases and review of electromyographic findings. Arch Intern Med 1989; 149: 2597600.

31. Vijayakuma A, Ashworth G, Thimmappa D. Thyrotoxic periodic paralysis: clinical challenges. J Thyroid Res 2014; 2014, ID 649502. doi:10.1155/2014/649502.

32. Paul B, Hirudayaraj P, Baig MW. Thyrotoxic periodic paralysis: an unusual presentation of Weakness. Emerg Med J 2003; e7.

33. Yeo P, O'Neill WC. Thyrotoxicosis and periodic paralysis. Medical Grand Rounds 1984; 3: 10-25.

34. Layzer RB. Periodic Paralysis and the Na K+ pump. Ann Neurol 1982; 11: 547-52.

35. Baumgartner FJ, Lee ET. Hyperthyroid hypokalemic periodic paralysis in a Hispanic male. J Natl Med Assoc 1990; 82: 133 4.

36. Lulsegged A, Wlodek C, Rossi M. Thyrotoxic periodic paralysis: case reports and an up-to-date review of the literature. Case Rep Endocrinol doi:10.1155/2011/867475.

37. McHutchison JG, Melick RA, Wark JD. Hypokalemic periodic paralysis of thyrotoxic origin. Aust N Z J Med 1987; 17: 455-56. 